\title{
The thermal signature of Aso Volcano during unrest episodes detected from space and ground-based measurements
}

\author{
Corrado Cigolini ${ }^{1}{ }^{2}$, Diego Coppola ${ }^{1}$, Akihiko Yokoo $^{3}$ and Marco Laiolo ${ }^{4}$
}

\begin{abstract}
The thermal signature of Aso Volcano (Nakadake) during unrest episodes has been analyzed by combining the MODIS-MIROVA data set (2000-2017) with high-resolution images (LANDSAT 8 OLI and Sentinel 2) and ground-based thermal observations (2013-2017). The site of major activity (crater 1 ) is located at the summit of the volcano and is composed by a fumarole field (located in the South Area) and an acidic lake (replaced by a Central Pit during Strombolian phases). The volcanic radiative power (VRP) obtained by nighttime satellite data during the reference period was mainly below $3 \mathrm{MW}$. This thermal threshold marks the transition from high fumarole activity (HFA) to Strombolian eruptions (SE). However, periods characterized by sporadic phreatic eruptions (PE, eventually bearing phreatomagmatic episodes), which is the prevalent phase during unrest episodes, exhibit very low VRP values, being around $0.5 \mathrm{MW}$, or below. The statistical analysis of satellite data shows that the transition from HFA to Strombolian activity (which started on August 2014 and ceased in May 2015) occurs when VRP values are above the cited 3 MW threshold. In particular during marked Strombolian phases (November-December 2014), the radiative power was higher than $4 \mathrm{MW}$, reaching peak values up to $15.6 \mathrm{MW}$ (on December 7, 2014, i.e., 10 days after the major Strombolian explosion of November 27). Conversely, ground-based measurements show that heat fluxes recorded by FLIRT440 Thermocamera on the fumarole field of the South Area has been relatively stable around 2 MW until February 2015. Their apparent temperatures were fluctuating around $490-575^{\circ} \mathrm{C}$ before the major Strombolian explosive event, whereas those recorded at the active vent, named Central Pit, reached their maxima slightly above $600{ }^{\circ} \mathrm{C}$; then both exhibited a decreasing trend in the following days. During the Strombolian activity, the crater lake dried out and was then replenished by early July, 2016. Then, volcanic activity shifted back to phreatic-phreatomagmatic and the eruptive cycle was completed. During this period, the MIROVA system detected very few thermal alerts and the ground-based measurements were fluctuating around $1 \mathrm{MW}$. The most violent explosion occurred on October 8, 2016, and within the following weeks measured VRP were moderately above $2 \mathrm{MW}$. This is coeval with a thermal increase at the fumarole field of the South Area, with temperatures well above $300^{\circ} \mathrm{C}$. Thermal monitoring at Aso Volcano is an additional tool in volcano surveillance that may contribute to near-real-time hazard assessment.
\end{abstract}

Keywords: Aso Volcano, Unrest episodes, Fumarolic activity, Strombolian activity, Major explosions

\section{Introduction}

Nakadake is the active center of the Aso caldera located in north-central Kyushu, Japan. It is also known as Aso Volcano or Asosan and its cater is composed by a

\footnotetext{
*Correspondence: corrado.cigolini@unito.it

1 Dipartimento di Scienze della Terra, Università degli Studi di Torino,

Via Valperga Caluso 35, Turin, Italy

Full list of author information is available at the end of the article
}

migrating fumarole field and an acidic crater lake (named Yudamari) which occupies the crater bottom within the northern sector.

It is generally accepted that crater lakes at active volcanoes are systematically affected by anomalous concentrations of volcanic gases and by hydrothermal fluids that rise from greater depths. Variations in fluid flow rates from below may induce substantial changes in the temperature and composition of fumarolic gases, which may 
be eventually accompanied by changes in the volume and morphology of the coexisting lake (e.g., Rouwet and Tassi 2011; Christenson et al. 2015; Hurst et al. 2015). However, the thermal monitoring of fumarolic areas is widely used to decode the signals of volcanic unrest at active volcanoes (Chiodini et al. 2007; Fischer et al. 2015; Shinohara et al. 2015). Concentrated degassing in areas surrounding the crater and/or in proximity of crater lakes may drastically increase before changes in volcanic activity that may lead to the onset of eruptive events. Overall, fumaroles located within or around crater lakes may exhibit the first signs of volcanic unrest, essentially given by variations in temperature and fluid flow rates. This process is generally associated with variations in the chemical composition of gases and may be eventually coupled with color changes within lake waters (e.g., Onda et al. 2003; Németh et al. 2006; Ohsawa et al. 2010; Fischer et al. 2015; Shinohara et al. 2015). Nowadays, satellite thermal data are widely used to monitor active volcanoes (Ramsey and Harris 2012, Harris 2013; Coppola et al. 2016a) but the detection and analysis of small thermal anomalies has been a rather stimulating challenge (e.g., Coppola et al. 2016b; Laiolo et al. 2017). This is essentially due to the fact that fumaroles are small thermal signals in comparison with lava flows and/or domes. To better decode thermal variations, TM-class sensors operating in the thermal infrared (TIR) region of the electromagnetic spectrum have also been used to collect systematic measurements (Oppenheimer 1993, 1996, 1997; Trunk and Bernard 2008; Bodruddoza Mia et al. 2014; Murphy et al. 2018). These sensors may arrive to $30-90 \mathrm{~m}$ pixel resolution and may be quite efficient in detecting and locating small hot spots (e.g., Harris 2013). Unfortunately, these types of sensors exhibit a rather poor temporal resolution ( 14-16 days) and may not detect the short-term fluctuations of the thermal signal, particularly during the onset of unrest episodes. Essentially for this reason AVHRR-class sensors (which provide several images per day with $1-\mathrm{km}$ pixel resolution on IR bands) have been used in tracking eruptive events (Dean et al. 1998; Dehn et al. 2002; Patrick et al. 2005) and to distinguish hot fumaroles fields from other sectors of the volcano (i.e., at Vulcano Island; Harris and Stevenson 1997).

In a recent paper, Laiolo et al. (2017) have used MODIS (moderate resolution imaging spectroscopy) data, analyzed by means of the MIROVA algorithm (Coppola et al. 2016a) in combination with higher resolution Landsat images, to evaluate volcanic unrest episodes related with the high-temperature fumaroles of Santa Ana volcano (El Salvador). The advantage of this refined algorithm is that we can satisfactorily use MODIS data, characterized by four overpasses per day to monitor our target volcano, i.e., a rather satisfying temporal resolution for near-realtime volcano surveillance.

In this paper, we present the thermal screening of Nakadake volcano by combining and analyzing, the 2000-2017 MODIS-MIROVA data set with higher resolution images provided by Landsat 8 OLI and Sentinel 2 images (since 2013 and 2015, respectively). The processed thermal signatures are then compared and discussed with ground-based geophysical data to delineate the timeline of unrest episodes coupled with the onset and duration of thermal anomalies. We focused our attention on the transition from phreatic-phreatomagmatic to strombolian eruptive styles. The final results contribute to unravel the relationships between the upper part of the magma body and the hydrothermal system which modulate the changes of the crater lake.

\section{Aso caldera and Nakadake volcano}

The Aso caldera located in north-central Kyushu (Fig. 1a) lies on the Beppu-Shimabara graben (Kamata and Kodama 1994; Takayama and Yoshida 2007) which shows an extensional component and is subdivided in several fault zones. The most active sector has been recently the strike-slip Futagawa Fault (Research Group for Active Faults of Japan 1991) that generated the Kumamoto earthquake (Mw 7, on April 15, 2016) and was followed by an intense seismic swarm. Rupture propagation terminated near the southwest side of Aso Volcano (Yagi et al. 2016). The Aso caldera is an N-S elongated structure, approximately 25 by $18 \mathrm{~km}$ wide. Four major eruptions (whose deposits are named Aso-1, Aso-2, Aso-3, and Aso-4) led to the formation of the caldera and occurred at 266, 141, 123, and $89 \mathrm{ka}$, respectively (Matsumoto et al. 1991). The last large eruption (Aso-4) produced more than $600 \mathrm{~km}^{3}$ of volcanic tephra and formed the present caldera (Committee for Catalog of Quaternary Volcanoes in Japan 1999). Since then, several minor eruptions took place within the central part of the caldera, forming the so-called central cones. In terms of magma composition, there is a high variability, from silicic to mafic, of the erupted lavas and tephra (Ono and Watanabe 1985; Hunter 1998; Kaneko et al. 2008). Currently, Nakadake is the only active volcano (Fig. 1a) and eruptive products are predominantly andesitic and basaltic (cf., Miyabuchi and Sugiyama 2011; Miyoshi et al. 2013). Some of them are distinctly related to Strombolian type of eruptions: such as the bomb-rich pyroclastic flow deposit described by Miyabuchi et al. (2006).

The recent volcanic history of Nakadake is rather complex due to the variability of unrest episodes. Sudo (2001) described its typical eruptive activity which can be synthesized in terms of an eruptive cycle involving the summit lake, named Yudamari (or Crater 1), and the active 

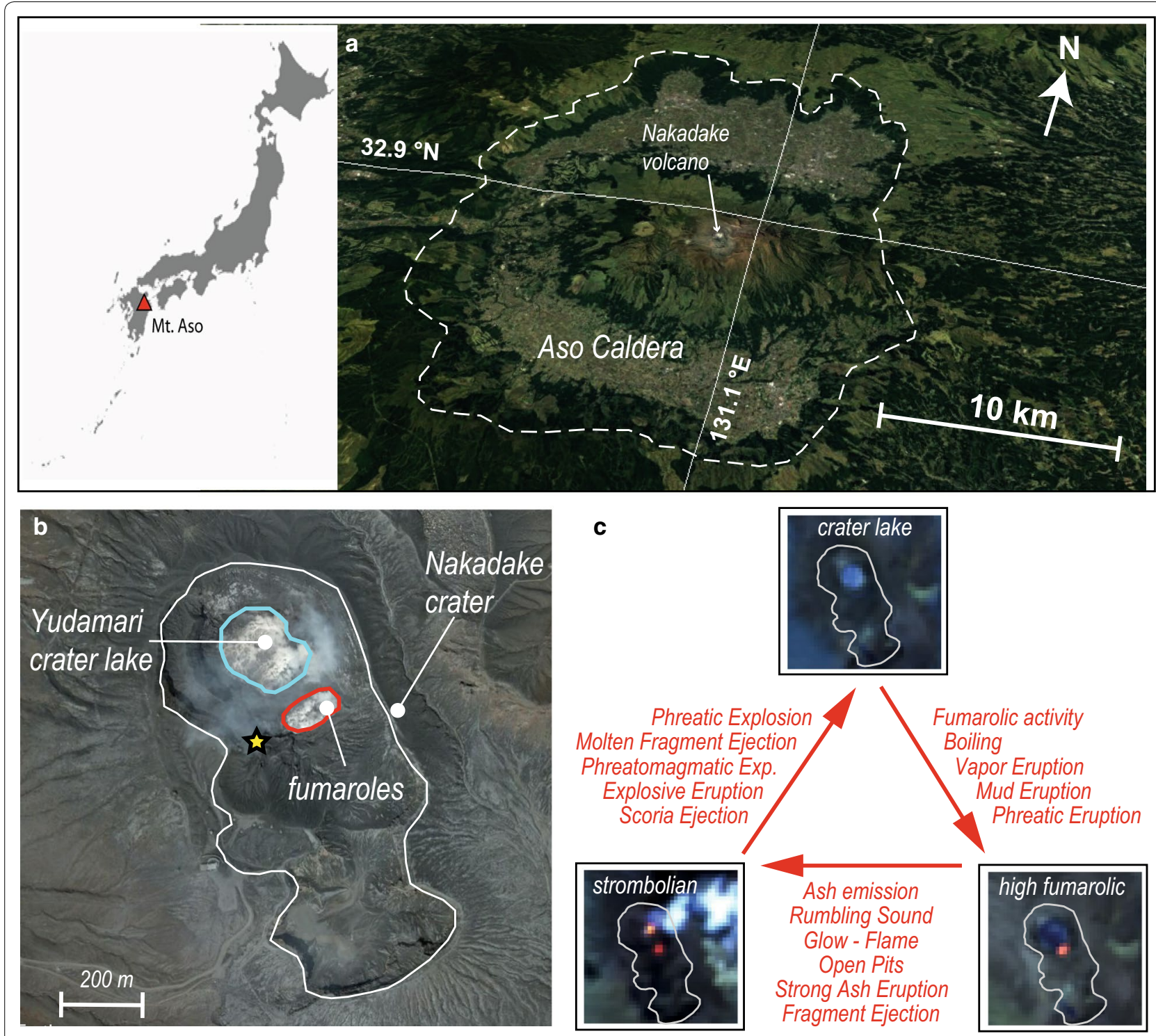

Fig. 1 a Aso caldera and Nakadake volcano in north-central Kyushu. b Google Earth snapshot of Nakadake crater; the star represents the site from where ground-based measurements were collected. The Yudamari crater lake and the fumarole field are also shown by cyan and red contours, respectively. c Schematic diagram of the cyclic volcanic processes at Nakadake crater (modified after Sudo 2001). The three representative Landsatclass images (false color RGB; R: $2.2 \mu \mathrm{m} ; \mathrm{G}: 1.6 \mu \mathrm{m} ; B: 0.8 \mu \mathrm{m}$ ) at the vertexes of the triangle illustrate the thermal pattern during the principal phases of activity (crater lake $\rightarrow$ high fumarolic $\rightarrow$ strombolian). Landsat images courtesy of ESA Copernicus Service Data Hub. See the text for details

fumaroles (Fig. 1b). During normal activity, the lake is white greenish and its temperatures are around $50-60^{\circ} \mathrm{C}$, fumaroles are normally active with temperatures $\sim 90^{\circ} \mathrm{C}$. An increase in the heat flux will induce the progressive evaporation of lake waters (which first become gray in color and then may partially and/or totally evaporate), and phreatic explosions may occur (e.g., Sudo 2001; Shinohara et al. 2015).

An additional growth in volcanic activity is accompanied by opening of small pits (of several meters) within the crater bottom, with the ejection of hot gases and volcanic ash leading to multiple incandescent spots. When this threshold is reached, the quantity of ejected ash drastically increases together with the diameters of the pits (which may arrive to tens of meters in diameter). A further increase in the activity will cause the transition to Strombolian activity with the ejection of juvenile materials from active vents. The onset of Strombolian activity occurs when the magma column reaches the surface and may last for weeks or months. At the end of this phase, 
the crater bottom is substantially buried and, within few months, the crater lake normally reappears. However, the volcano can be still affected by violent phreatomagmatic and phreatic explosions. The cycle (Fig. 1c) is then completed with the progressive ceasing of eruptive episodes.

In the light of the above, we will now analyze the chronology of unrest phenomena that occurred at Nakadake within the last 28 years: Some of them overlap with the time series of data we are presenting.

Following the Strombolian activity of November 1989, several phreatomagmatic eruptions occurred until 1991; these were replaced by phreatic eruptions (up to VEI 2) in 1992, 1994, and 1995. The early transition from ash fallout activity to Strombolian (Ono et al. 1996; Sudo 2001) has been analyzed by Yokoo and Taniguchi (2004) who reconstructed, by video-image processing, that the speed of pressure waves during the onset of Strombolian activity reached $200-300 \mathrm{~m} / \mathrm{sec}$. A crater lake, named Yudamari, formed at the summit area of Nakadake (early 1990) and its temperature was above $90{ }^{\circ} \mathrm{C}$ during mid-1992, then fluctuated around $50-70{ }^{\circ} \mathrm{C}$ until the end of 1996. Then, the temperature stabilized between 40 and $60{ }^{\circ} \mathrm{C}$ until the very beginning of 2003 , when an increasing trend took place within that year with temperatures reaching $\sim 80{ }^{\circ} \mathrm{C}$. From the beginning of 2001 to the end of 2004, hot glowing fumaroles have been observed within Nakadake crater (Japan Meteorological Agency 2013; Global Volcanism Program 2015). Through 2003-2005 few phreatomagmatic eruptions (which involved nearly $10 \%$ of juvenile material) were observed and have been ascribed to magma rise (e.g., Ikebe et al. 2008; Miyabuchi et al. 2008). During this span of time, two main ash falls were recorded in 2003 and 2004, and from 2008 to February 2009, the area surrounding the crater was affected by several tephra falls. During midJuly 2010, volcanic unrest was characterized by a seismic swarm bearing high tremor amplitude (cf., Nobile et al. 2017; Japan Meteorological Agency 2013; Global Volcanism Program 2015). In this period, hot glowing fumaroles were actively degassing at the rim of the crater lake. Eruptive episodes were recorded during May-June 2011 with a new tephra fall. Koike et al. (2014) detected the change in radon concentration within geothermal reservoirs of Aso caldera and compared it with some of the earlier eruptions that occurred at Mount Aso. Phreatomagmatic activity was resumed during January-February 2014 accompanied by moderate seismicity. Then, during the summer-fall of 2014 Nakadake entered a period of marked eruptive unrest characterized by Strombolian activity that culminated with the major explosion of November 27, 2014 (Japan Meteorological Agency 2013; Global Volcanism Program 2015). During the fall of 2014, the summit lake practically disappeared and the crater was substantially occupied by an active vent with moderate to sustained Strombolian activity (such as the eruption of November 27, 2014). This activity produced low-altitude but persistent ash plumes (Fig. 2) until the beginning of May 2015.

In the following months, waters accumulated within crater and the lake progressively grew up again. During this span of time ,fumaroles were particularly active (cf., Terada and Hashimoto 2017). McKee et al. (2017) estimated, by means of an infrasonic array, that during July-August 2015 the exit velocity of the fumarole of the central vent reached values of $\sim 79$ to $132 \mathrm{~m} / \mathrm{s}$. During late 2015 and throughout the 2016, several violent phreatic and phreatomagmatic explosions occurred. The most violent, on October 8, 2016 ejected ballistic projectiles associated with an ash column, approximately $11 \mathrm{~km}$ high, which collapsed generating incipient pyroclastic flows in the surroundings. The summit area has been covered by $50-100 \mathrm{~cm}$ ash and tephra and the crater lake disappeared. Volcanic activity was then declining (Global Volcanism Program 2016, 2017).

Considering the above chronology, we will now synthesize what is known about the inner feeding system of Aso Volcano. Yamamoto et al. (1999) by analyzing volcanic tremors suggested that an almost vertical $2.5-\mathrm{km}$-long crack-like conduit (dipping west-southwest) is responsible of transferring volcanic gases to summit the crater. However, seismic tomography detected a low-velocity body at a depth of $6 \mathrm{~km}$, laying $3 \mathrm{~km}$ west from the active crater (Sudo and Kong 2001).

Long-term leveling survey data obtained from 1937 to 2004 (Sudo et al. 2006) revealed the existence of a deformation source near the previously detected low-velocity body of Sudo and Kong (2001) (with a deflation of $\sim 7 \mathrm{~cm}$ ) being indicative of a magma chamber, that by supplying the gases to the crater, undergoes deflation. An additional evidence of high-temperature fluids/magma migrating to the surface is given by the 3-D seismic reflection analysis of Tsutsui and Sudo (2004) who detected an area with no reflections at a depth of $1.5-3.5 \mathrm{~km}$ below the crater.

However, on the basis of GPS data, the Geographical Survey Institute (2004) suggested that a sill-like dilatation source (with dimensions of $4.8 \mathrm{~km}$, running $\mathrm{N}-\mathrm{S}$, by $4.4 \mathrm{~km}$, running $\mathrm{E}-\mathrm{W}$ ) is located at an approximate depth of $15.5 \mathrm{~km}$ beneath the eastern flank of the central cones (with a vertical opening of about $70 \mathrm{~cm}$ during the middle of 2003). More recently, Ohkura and Oikawa (2012) detected, also by means of GPS data, two deformation sources (one compatible with the magma chamber at $6 \mathrm{~km}$ depth, and the other one related to the sill-like source) which were deflating during 1997-2003 and during 2004-2008. Ohkura and Oikawa (2012) also estimated the overall deflation of the two sources matches 


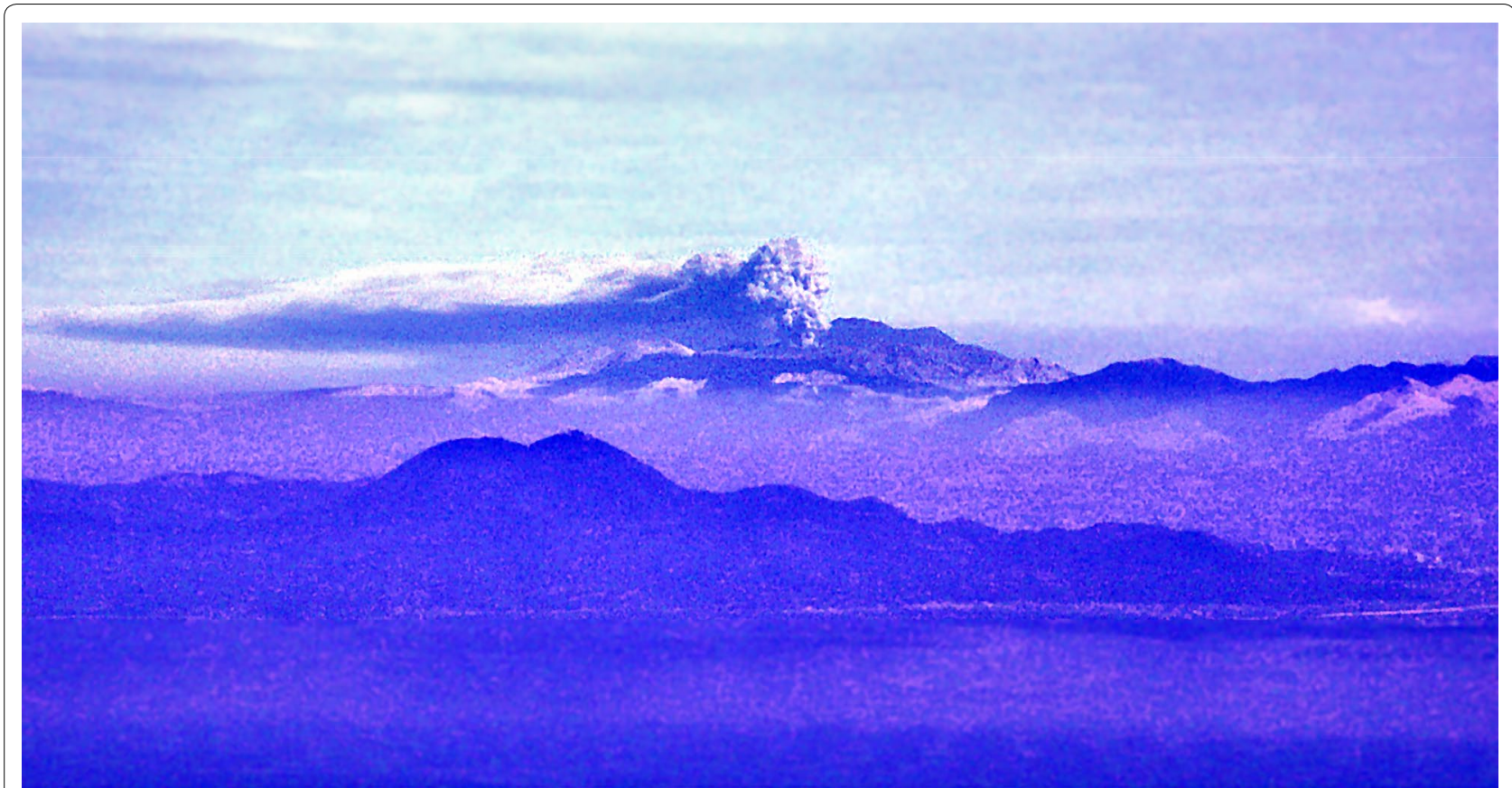

Fig. 2 The active ash-plume above Nakadake on January 18, 2015, during a period of sustained Strombolian activity. The plume reaches approximately $600 \mathrm{~m}$ above the active crater. Photograph taken from Unzen volcano looking ENE along the Bebbu-Shimabara graben. In the foreground the Shimabara Bay

the volume of gases emitted during the same period (i.e., $9 \times 10^{6} \mathrm{~m}^{3}$ from 2004 to 2008). Subsidence persisted until 2011 (Unglert et al. 2011). Recent geophysical studies (Abe et al. 2010) have shown the existence of a deeper low-velocity layer (between 10 and $24 \mathrm{~km}$ ) beneath the western sector of the caldera, likely containing up to $15 \%$ of melt or $30 \%$ aqueous fluid. More recently, Abe et al. (2016), through an accurate analysis of the receiver functions from teleseismic waveform data, confirm the above observations and detected a low-velocity zone at a depth of $8-15 \mathrm{~km}$ beneath the eastern flank of the central cones. Moreover, they located the foci of low-frequency earthquakes (deep low-frequency earthquakes, DLFEs) that cluster just below the sill-like deformation source; finally they inferred the existence of a second low-velocity zone extends in and around the caldera at a depth of $15-23 \mathrm{~km}$.

\section{Methods}

The volcanic radiative power (VRP) was retrieved from the IR (InfraRed) data acquired by MODIS (Moderate Resolution Imaging Spectroradiometer) and automatically processed by means of the MIROVA algorithm (Coppola et al. 2016a). The MODIS sensors are mounted on Terra and Aqua satellites and were launched by NASA (National Aeronautics and Space Administration) on February 2000 and May 2002, respectively. The moderate resolution (1-km pixel resolution) and the relative short time of overpasses (four images per day at equatorial latitudes), combined with the MIR (Middle InfraRed) wavelengths, make this sensor reliable for a continuous monitoring of volcanic activity at a global scale (cf. Wright et al. 2002; Rothery et al. 2005; Coppola et al. 2016a).

The MIROVA algorithm uses the Middle InfraRed (MIR) data acquired by MODIS images and applies spatial and spectral constraints to detect, locate, and quantifying thermal anomalies on the investigated area $(50 \times 50 \mathrm{~km}$ box for any "target" volcano; Fig. 3a). The volcanic radiative power (Watt) is calculated according to the Wooster's MIR-method (Wooster et al. 2003), as follows:

$$
\mathrm{VRP}_{\text {PIX }}=18.9 \times A_{\text {PIX }} \sum_{1}^{n} \times\left(L_{4 \text { alert }}-L_{4 \mathrm{bk}}\right)
$$

where the $L_{4 \mathrm{alert}}$ and $L_{4 \mathrm{bk}}$ are the $4 \mu \mathrm{m}(\mathrm{MIR})$ radiance (W $\mathrm{m}^{-2} \mathrm{sr}^{-1} \mu \mathrm{m}^{-1}$ ) of each alerted pixel/s and local background, respectively; $A_{\text {PIX }}$ is the pixel size $\left(1 \mathrm{~km}^{2}\right.$ for MODIS resampled data), $n$ is the number of alerted pixels. Equation (1) can be successfully applied in analyzing thermal anomalies comprised between 500 and $1500 \mathrm{~K}$ (cf. Wooster et al. 2003; Eq. 6 of their work). This parameter may range from less than $1 \mathrm{MW}$ to 


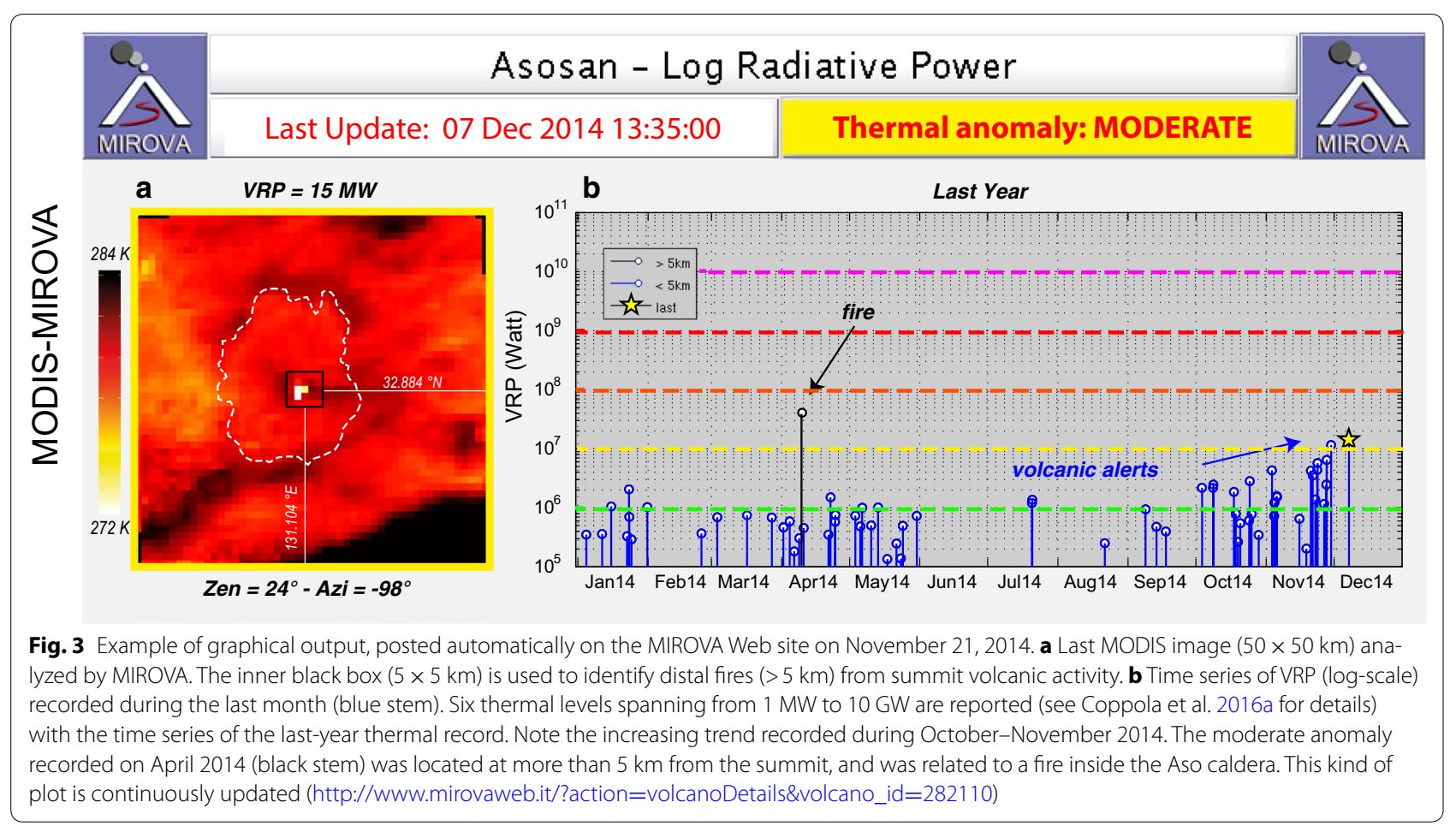

more than $40 \mathrm{GW}$ at active volcanoes (cf. Coppola et al. 2016a). Currently, the algorithm of Eq. (1) is encapsulated in the fully automated MIROVA platform; a nearreal-time hot spot detection system which is thermally monitoring over 200 of the most active volcanoes on the earth (www.mirovaweb.it). Nowadays, the system is actively monitoring 11 Japanese volcanoes including Aira (Sakurajima), Kusatsu-Shirane crater lake, and Nishinoshima among others (see http://www.mirovaweb. it/?action=nrt\#Japan). Daily results are posted automatically on the Web site (an example shown in Fig. 3) within 1-4 h/s since image acquisition (cf. Coppola et al. 2016a).

The system has been very practical in responding to effusive crisis at Stromboli (Valade et al. 2016), Piton de la Fournaise (Coppola et al. 2017a; Harris et al. 2017) and Bardarbunga-Holuhraun (Coppola et al. 2017b) as well as for monitoring, in near-real time the growth and evolution of lava-lake activity at Nyamulagira volcano (Coppola et al. 2016c). Nonetheless, it has been particularly efficient in detecting low thermal activity related to the slow extrusion of viscous lava bodies at Ubinas (Perù) and Nevado de Chillan (Chile) (Coppola et al. 2015, 2016b) as well as to identify the development of an hightemperature fumaroles field at Santa Ana Volcano, El Salvador (Laiolo et al. 2017).

The entire dataset of nighttime MODIS images consists of 12,368 elements. Until June 30, 2017 less than 5\% (601 in total) have shown at least one alerted pixel. The
MIROVA system automatically recognized 590 images characterized by anomalies located in a $5 \times 5 \mathrm{~km}$ box, centered on the coordinates of the volcano (Fig. 3a), whereas 11 alerts were detected at more than $5 \mathrm{~km}$ from the summit and were likely related to fires. All the anomalies were checked by eye inspection to confirm that such thermal anomalies were related to a volcanic origin (Coppola et al. 2016a).

In addition to the moderate resolution $(1 \mathrm{~km})$ IR data provided by MODIS, we analyzed higher resolution $(30 \mathrm{~m})$ IR data acquired by the LANDSAT 8 (https://landsat.usgs.gov/landsat-8) and the SENTINEL 2 (https:// sentinel.esa.int/web/sentinel/missions/sentinel-2) missions, respectively. These two satellites monitor land surface conditions of the entire globe since March 2013 and June 2015, respectively, with a typical revisit time between 8 and 16 days. Landsat 8 and Sentinel 2 provide multispectral data in 11 and 13 bands, respectively, and both have the three channels (centered at $\sim 2.2, \sim 1.6$ and $\sim 0.85 \mu \mathrm{m})$ typically used for hot target detection (Murphy et al. 2017). Full and open access to the data is provided free of charge by the ESA's (European Space Agency) Copernicus Service Data Hub (https://cophub. copernicus.eu/dhus/\#/home). Instead of downloading the large amount of data archived in the packed swaths of Landsat-class images, we used the "Sentinel Playground" a cloud-based GIS platform developed by Amazon, for distribution, management, and analysis of satellite data 

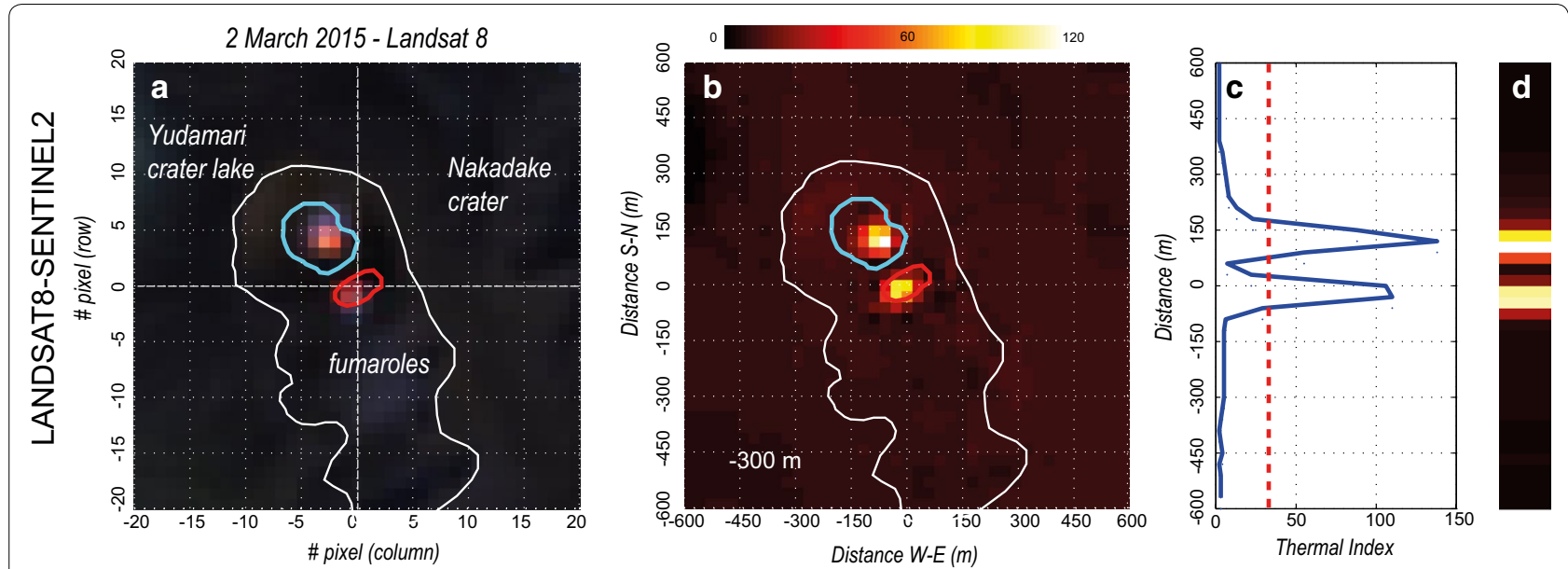

Fig. 4 Elaboration sequence of high-resolution images a False color ( $R: 2.2 \mu \mathrm{m} ; \mathrm{G}: 1.6 \mu \mathrm{m} ; B: 0.8 \mu \mathrm{m})$ Landsat 8 image acquired over Asosan volcano on March 2, 2015. This kind of maps is automatically downloaded from Amazon Sentinel Playground; $\mathbf{b}$ Thermal index (TI) map calculated from the RGB image according to Eqs. 2 and 3. Note how the thermal anomaly produced by the fumarole field becomes more evident; c Stacked vertical profile obtained by calculating the maximum TI of each row. $\mathbf{d}$ Color bar derived from the thermal profile shown in c

(http://www.sentinel-hub.com/). This system allows composing, cropping and downloading the full datasets of Landsat 8 OLI and Sentinel 2, by using the cloud service provided by Amazon Web Service S3 (AWS-S3). We thus developed a simple routine that queries the AWS-S3 system for any satellite overpass centered on Nakadake crater, and composed a false color RGB image $(R: 2.2 \mu \mathrm{m}$; $G$ : $1.6 \mu \mathrm{m} ; B: 0.8 \mu \mathrm{m})$ for an area of $40 \times 40$ pixel $(1200 \mathrm{~m}$ by side) as shown in Fig. 4a.

The complete dataset acquired between 2013 and 2017 over this small box consists of 110 images. Importantly, the false color images generated by AWS-S3 system are provided with gain and gamma equal to 1 so that the RGB indexes (scale of values between 0 and 255) are directly proportional to the digital number $(\mathrm{DN})$ of the original granules. Therefore, in order to detect the presence of hot spot, we develop an algorithm that operates on the RGB indexed images rather than with the original radiance data (such as the HOTMAP algorithm; Murphy et al. 2017), but essentially with the same principles.

The algorithm is based on the calculation of three of thermal indexes (TI) according to:

$$
\begin{aligned}
& \mathrm{TI}_{R-G}=R-G ; \\
& \mathrm{TI}_{R-B}=R-B ; \\
& \mathrm{TI}_{G-B}=G-B ;
\end{aligned}
$$

where $R, G$ and $B$ are the indexed values $(0-255)$ of the red $(2.2 \mu \mathrm{m})$, green $(1.6 \mu \mathrm{m})$ and blue $(0.8 \mu \mathrm{m})$ component, respectively. Hence, for each pixel the maximum value of the three indexes is considered so that:

$$
\mathrm{TI}=\max \left(\mathrm{TI}_{R-G}, \mathrm{TI}_{R-B}, \mathrm{TI}_{G-B}\right)
$$

An example of the resulting TI map is shown in Fig. 4b. Note how the two hot spots located on the Yudamari crater lake and fumarole field (reddish to orange in Fig. 4a) are characterized by high TI with respect to the surrounding. The contrast is particularly evident in the stacked vertical profile shown if Fig. 4c where we plotted the maximum TI value for each row. The two hotspot's areas appear as evident peaks, reaching TI well above the value of 50. On the contrary, the surrounding areas have TI values always below 20. A conservative threshold of $\mathrm{TI}=40$ (red dashed line in Fig. 4c) is thus used to classify a pixel as hot spot contaminated.

In addition to satellite thermal monitoring, groundbased thermal infrared observations at Aso Volcano were repeatedly conducted to track temporal evolution of surficial thermal activity at the active crater (Crater 1, Fig. 5). For the observation, we used a handy camera T440 (FLIR Systems Inc.; temperature range -20 to $1200{ }^{\circ} \mathrm{C}$, resolution $320 \times 240$ pixels, and field of view $25^{\circ} \times 19^{\circ}$ ) to take several images (usually $5-6$, sometimes more than 10 images) from the fixed location on SSW rim of the crater (Fig. 1a). At a distance of $200 \mathrm{~m}$ to the south-wall fumarole area (Fig. 5), the size of one pixel of the image equates to an area of $0.078 \mathrm{~m}^{2}$. Frequency of observations were every 10 days in average (recent 160 data were acquired in 1660 days $=4.5$ years).

We estimated the heat flux using a following equation given by Sekioka and Yuhara (1974) and Matsushima et al. (2003):

$$
Q=K \sum \Delta T \cdot S
$$




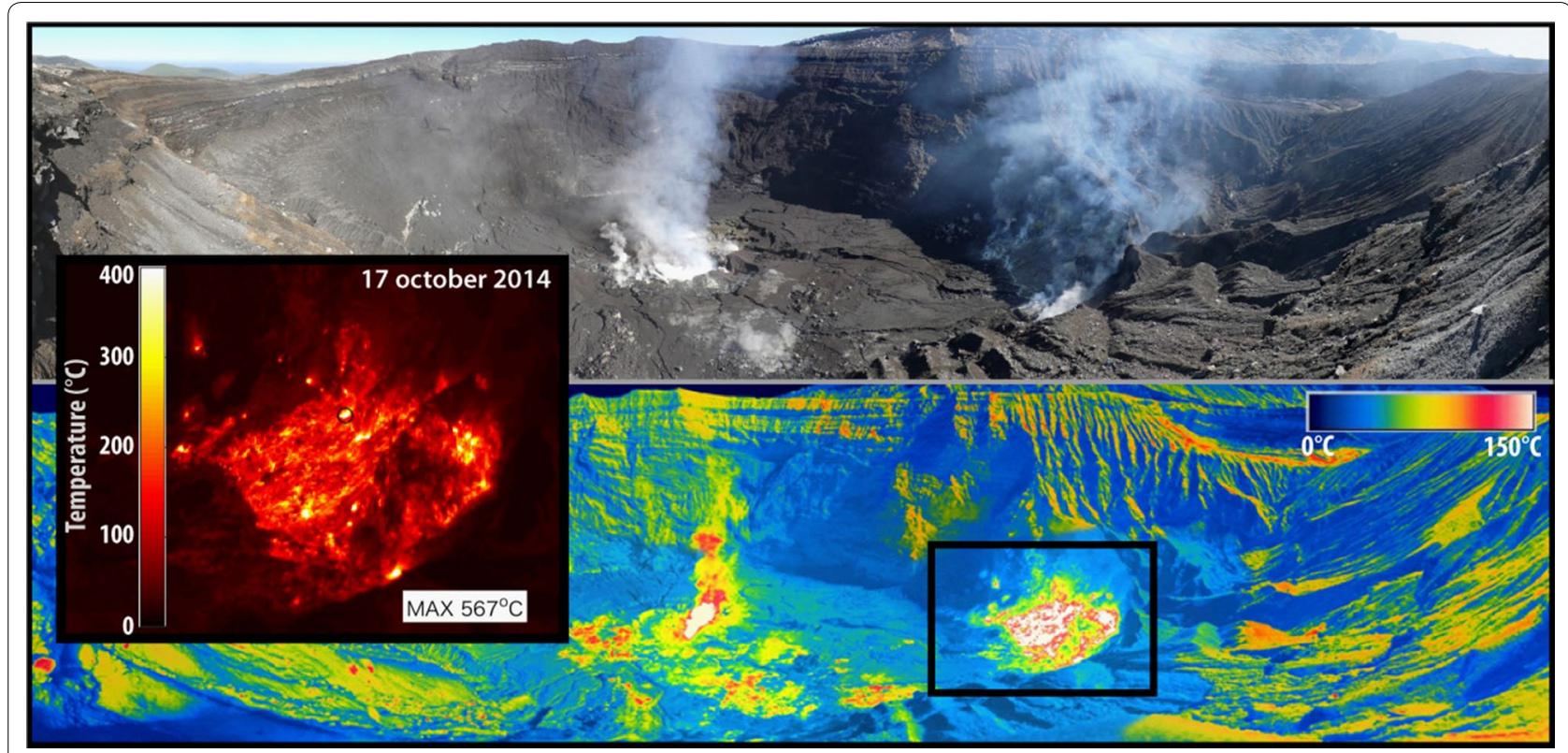

Fig. 5 Visible and thermal infrared panoramic images taken from the fixed observation position at Aso Crater 1 rim (star in Fig. 1) on October 17, 2014. Inset shows the image of the fumarole field located in the South Area (indicated by the black rectangle) with the maximum apparent temperature recorded during ground-based measurements

where $\Delta T$ is the temperature difference from a "thermally normal" area, $S$ is the total anomalous area with $\Delta T$, and $K$ is an empirical coefficient depending on meteorological conditions, such as wind velocity, humidity, air temperature, and other factors. Thermal anomaly area is defined as the surface area with the temperature higher than $T_{0}+3 \sigma$ (Kagiyama 1981). The normal temperature $T_{0}$ and the standard deviation $\sigma$ are statistically determined from the acquired thermal infrared image (Fig. 5). Following Sekioka (1983), we set a value of $K=39 \mathrm{~W} /$ $\mathrm{m}^{2} \mathrm{~K}$, being consistent with the relationships reported by Matsushima et al. (2003).

\section{Results}

We will first analyze and discuss the long-term volcanic radiative power (VRP) collected from 2000 to 2017 and then concentrate in probing the transition from phreatic-phreatomagmatic to Strombolian activity (and vice versa), by taking into account ground-based thermal measurements.

In Fig. 6a, we present the 2000-2017 radiant fluxes, calculated by MIROVA at Nakadake, compared with the principal eruptive phases depicted by on site observations and independent reports (Japan Meteorological Agency 2013; Global Volcanism Program 2015, 2016, 2017). We also referred to Nobile et al. (2017) who synthesize the activity of Aso Volcano since 1989.

The calculated volcanic radiative power (VRP) values spanned from less than $0.1 \mathrm{MW}$ to a maximum of
$15 \mathrm{MW}$, with an overall average of $0.9 \mathrm{MW}$ throughout the analyzed period. Therefore, the thermal activity at Aso Volcano was, in general, very low ( $<1 \mathrm{MW}$; cf. Coppola et al. 2016a). On the other hand, thermal alerts showed a rather regular persistence during the entire time series. This is consistent with the fact that the average repose time (time encompassed between two successive recorded anomalies) is $\sim 10$ days, with the longest period of thermal rest ( 300 days $)$ recorded between January and October 2016 (Fig. 5a). The frequency of thermal alerts, hereby calculated on a monthly scale (cf. $f_{\text {alert }}$ in Coppola et al. 2013), spans from $1 \%$ to a peak values that reach $25 \%$ (November 2014), with average values of about $6 \%$, being consistent with 4 alerted images for month.

It can be noted that during phases of sporadic phreatic events (PE) or tephra/ash release, the thermal activity was very low $(<0.5 \mathrm{MW})$ or absent. Conversely, periods characterized by high fumaroles activity (HFA) exhibited a longer persistence of thermal anomalies with VRP often comprised between 1 and $2 \mathrm{MW}$. In particular, the long-term cycles of HFA (glowing fumaroles) were recorded by relatively intense satellite thermal anomalies during 2001-2003 and 2009-2010. In both cases, an incandescence of a sector of the southern crater wall has been recorded, with temperatures above $500{ }^{\circ} \mathrm{C}$, and temperatures of the water lake reaching about $80^{\circ} \mathrm{C}$ (cf., JMA 2013). VRP values were approaching $2 \mathrm{MW}$ during early 2003 , with a temporary maximum $(\sim 3 \mathrm{MW})$ in 

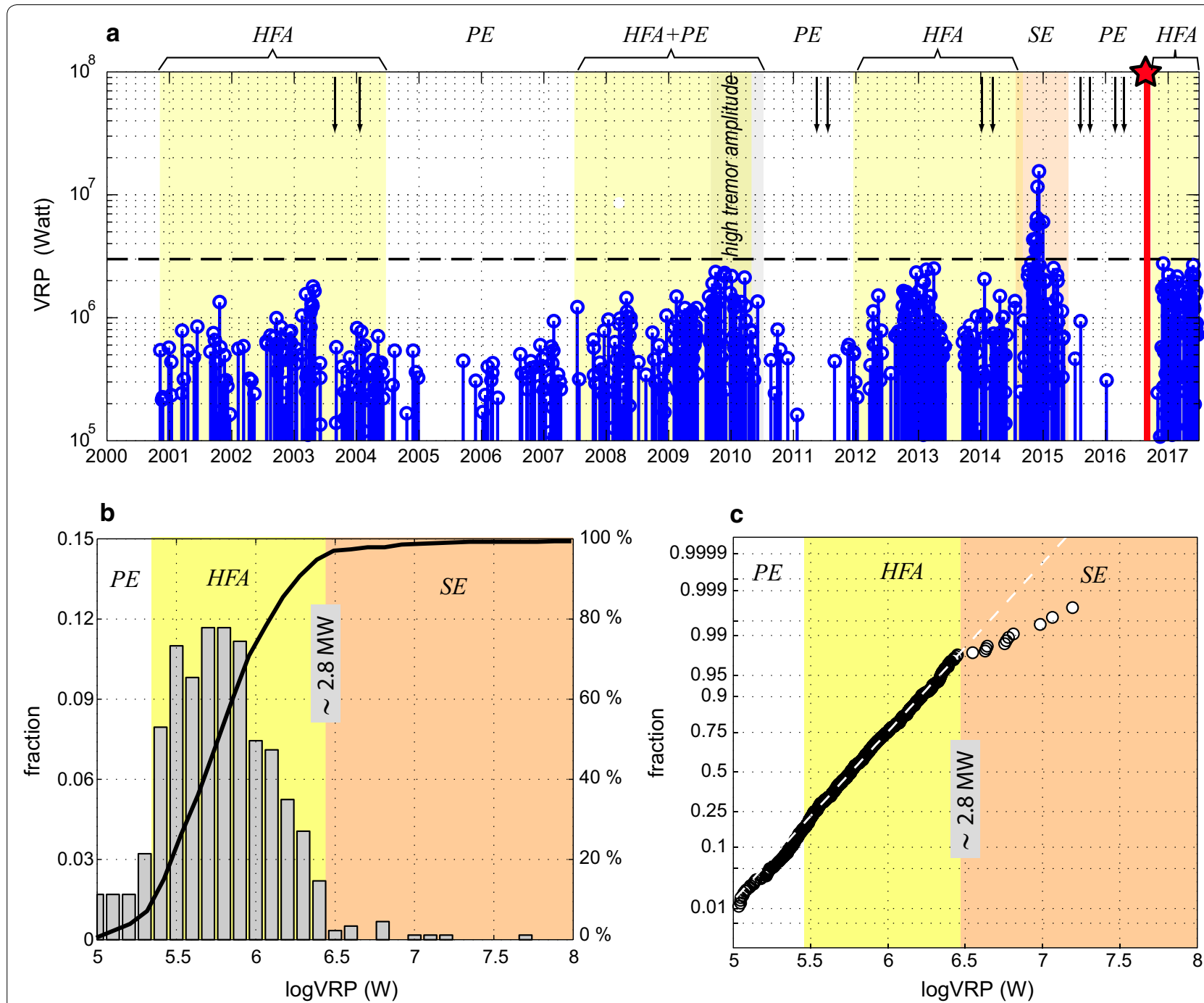

Fig. 6 a Time series of volcanic radiative power (VRP) recorded at Aso volcano between 2000 and 2017. Colored field indicate the principal phases of activity (PE: Phreatic and/or phreatomagmatic events; HFA: high fumarolic activity; SE: Strombolian eruptions). The red star indicates the timing of a major phreatomagmatic explosion occurred on October 8, 2016, after the longest period of thermal rest. b Statistical distribution of VRP data (log-transformed). c Probabilistic plot of VRP data (log-transformed) showing two clear populations separated at 2.8 MW. The arrows represent the main phreatomagmatic events and ash falls

2009-2010 (see Fig. 6a). The latter phase was also characterized by higher seismicity (i.e., high and persisting tremor), which was followed by a period of declining thermal signals, on 2011, characterized by several phreatic episodes.

A new cycle of increasing VRP can also be observed from 2012 to mid-2013 which also recorded and increasing trend in lake temperatures (up to $70^{\circ} \mathrm{C}$ ) coupled with spot-like incandescence of the southern wall (JMA 2013). This high fumarole activity (HFA) was the prelude to the onset of Strombolian eruptions (SE).

The marked phase of strombolian activity (from August 2014 to May 2015) that affected Nakadake is the sole span of time when the radiative power exceeded $10 \mathrm{MW}$, reaching peak values up to $15 \mathrm{MW}$ on December 7, 2014 (i.e., 10 days after the intense explosion of November 27). Within the following months, phreatic events were accompanied by thermal detections that were lower in number and intensity. However, enhanced thermal activity started again on November 2016 and has been preceded, on October 8 , by a strong explosion with the ejection of an 11-km-high ash column associated with incipient pyroclastic flows within the summit area (GVP 2016). The ongoing thermal activity (2017) is characterized by a high frequency in the alert detection $(15 \%$ on 
average) with VRP values approaching $3 \mathrm{MW}$, suggesting the persisting high fumarole activity.

Statistical analysis of VRP data gives us the opportunity to better analyze the acquired dataset and to recognize distinct thermal regimes related to observed type of activity (e.g., Coppola and Cigolini 2013; Coppola et al. 2014). At Aso Volcano, the distribution of the volcanic radiative power (VRP) shows low-intensity (i.e., $<3 \mathrm{MW}$ ) thermal anomalies (for about $97 \%$ of the dataset) with just two images exceeding $10 \mathrm{MW}$ (cf. Fig. 6b). These peak values were only recorded during November-December 2014, when the eruptive style was characterized by frequent strombolian explosions within a single crater (crater $n$. 1) producing the ejection of scoria bombs, lapilli, and ash onto the crater rim (cf. Global Volcanism Program 2015).

On the normal probabilistic plot (see Fig. 6c), we can easily identify and quantify two distinct populations which summarize the whole VRP dataset acquired at Nakadake. A distinct change point in the slope of the normal distribution can be observed at about 2.8 MW, with VRP values above such a value defining a different trend (i.e., approximately $2 \%$ of the entire dataset). This thermal threshold substantially marks the transition from high fumarole activity (HFA) to strombolian eruptions (SE) is also evidenced by the fact that higher thermal anomalies were detected exclusively from November 2014 to March 2015 (Fig. 5a). The analysis of the time series also indicates that periods characterized by $\mathrm{PE}$ activity typically show VRP values $<0.5 \mathrm{MW}(\operatorname{logVRP}=5.7)$ despite a clear distinction on the probability plot cannot be observed (Fig. 5c). This suggests that the transition between PE and HFA is represented by one single population of data, likely reflecting a unique process characterized by a continuum of thermal energy release. Conversely, the transition from HFA to SE is represented by the occurrence of a new population of data, likely related to a change in the source of the anomalies, i.e., hydrothermal versus magmatic origin.

In summary, the analysis of the 2000-2017 dataset confirms that two major factors induced thermal anomalies at Nakadake. These are the "glowing fumaroles" and the source of strombolian activity (cf. crater 1; Sudo 2001); both are characterized by distinct intensities of radiant flux detected from satellite images.

\section{The transition from phreatic-phreatomagmatic to Strombolian activity}

We will now analyze the transition from phreatic-phreatomagmatic to strombolian activity and vice versa, in the light of satellite data and ground-based measurements collected at Nakadake since 2013.

In Fig. 7, we report a comparative diagram with the whole MIROVA time series together with the data collected by the thermal camera located in the western side of the crater. Four LANDSAT 8 OLI images (Fig. 7) that depict the different stages of evolution of this transition are also reported. In general, there is a basic agreement between the magnitudes of radiative power of the two data sets during early-mid-2014 (Fig. 7b). However, during the beginning of that year the apparent temperatures measured at the southern wall of the crater (hereby defined as South Area) reached values of about $600{ }^{\circ} \mathrm{C}$, and those of the Central Pit (crater 1) had a drastic increase (up to $\sim 400{ }^{\circ} \mathrm{C}$ ) accompanied by the drying out of the crater lake (Fig. 7a, second image). In the following months, the heat flux and the temperatures of the fumarole field of the South Area were rather stable, whereas those of the Central Pit (Crater 1) first fell below $200{ }^{\circ} \mathrm{C}$, then fluctuated from $120^{\circ}$ to $380{ }^{\circ} \mathrm{C}$ in April; it drops again below $200{ }^{\circ} \mathrm{C}$ during early July and since then it shows and increasing trend, above $400{ }^{\circ} \mathrm{C}$. The end of August 2014 marks the transition from phreatic-phreatomagmatic to Strombolian activity (e.g., Nobile et al. 2017).

An increasing trend was also recorded by MIROVA within the first decade of September and peaked (at $15.6 \mathrm{MW}$ ) about 11 days after the major explosion of November 27, 2014. On that date, the apparent temperature recorded at the Central Pit reached its maximum value well above $600{ }^{\circ} \mathrm{C}$. Noticeably, the heat flux recorded by the thermal camera on the fumarole field of the South Area has been relatively stable around $2 \mathrm{MW}$ until February 2015. The temperatures of the fumarole field (South Area) were slightly fluctuating (around 490$575{ }^{\circ} \mathrm{C}$ ) before the explosive event (of October 8,2016 ) and started to exhibit a decreasing trend in the following days.

In the light of the above, it can be inferred that the "apparent discrepancy" between the radiative power recorded by MIROVA and the one measured by the FLIR camera is essentially due to the fact that satellite data are systematically affected by both the intra-crater thermal anomalies, i.e., the one of the Central Pit together with the one on the South Area, where the fumarole field is located.

Anyhow, all the recorded parameters follow a relatively regular decreasing trend after the major explosion of November 27, 2014. Conversely, the temperatures of the Central Pit show a rather abrupt decrease, down to about $150{ }^{\circ} \mathrm{C}$ by mid-January 2015 , and then fluctuate from below $100-220{ }^{\circ} \mathrm{C}$ until the end of June. This time span overlaps the ceasing of the Strombolian cycle, which occurs at the beginning of May (e.g., Nobile et al. 2017). A thermal pulse was then recorded in late Julyearly August 2015 (with apparent temperatures reaching $360{ }^{\circ} \mathrm{C}$ ) followed by a decreasing trend below $100{ }^{\circ} \mathrm{C}$ that 


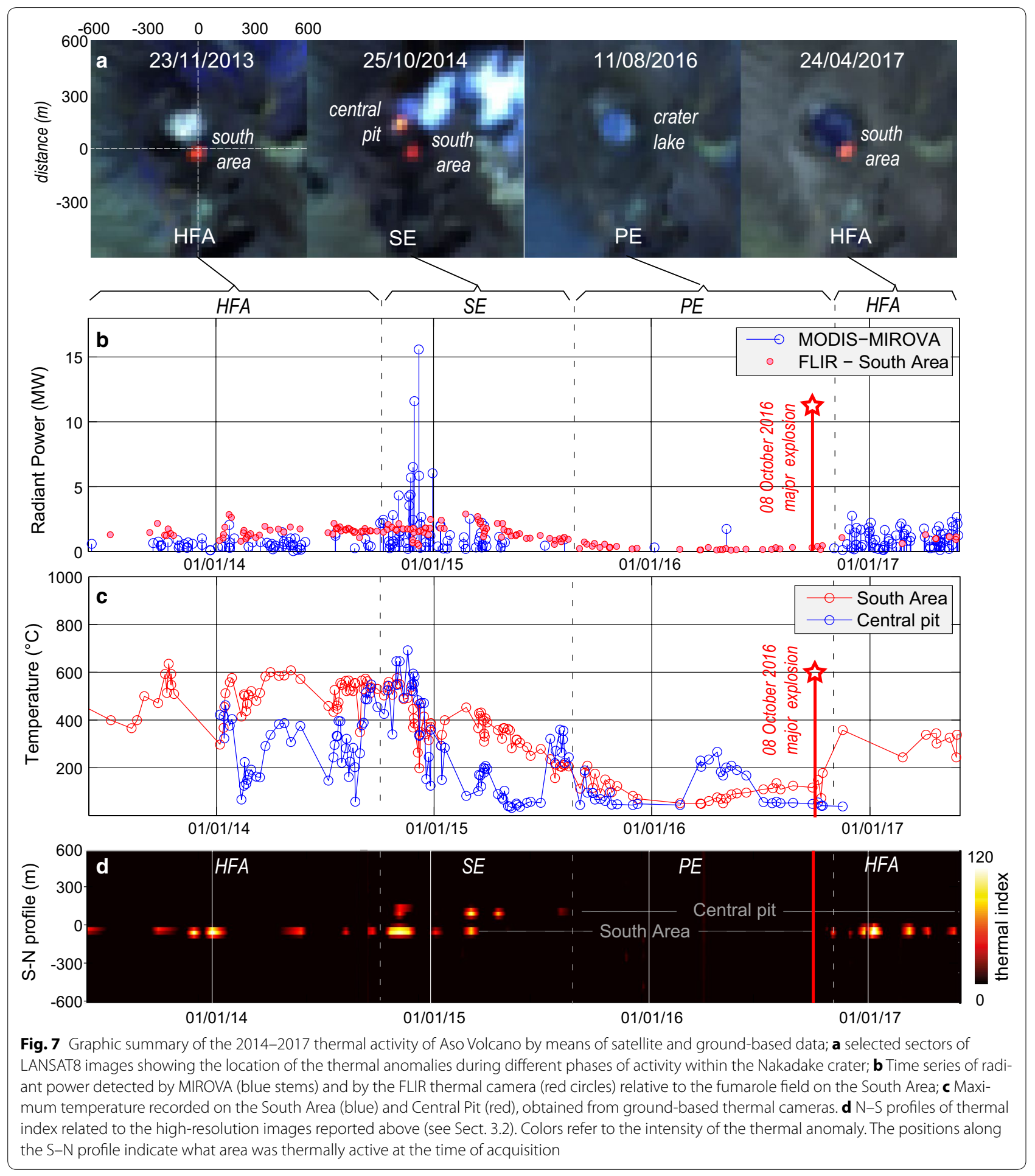

marks the reappearance of crater lake (late September 2015). Conversely, both temperatures and the heat flux recorded at the South Area have a moderate constant decrease until mid-February 2016, when they reach their minima, and then progressively rise being always below
$300{ }^{\circ} \mathrm{C}$ and $1 \mathrm{MW}$, respectively. Also the temperatures of the Central Pit moderately rise from March 23 to June 8, 2016 reaching a relatively high value, of $\sim 270{ }^{\circ} \mathrm{C}$, on April 20 . During this period, the crater lake dried out and was then replenished by July 6,2016 . We have to emphasize 
that the paucity of alerts detected by MIROVA from April 25, 2015 to November 24, 2016 is essentially related the relatively low values of thermal flux of the fumarole field (which, according to ground-based measurements, fluctuated around $1 \mathrm{MW}$ at the end of April, and then dropped below) coupled with the low temperatures of the Central Pit and the South Area (cf. Fig. 7a, third image from left). It is interesting to note that, following the major phreatomagmatic explosion of October 8, 2016, MIROVA started to detect alerts well above $1 \mathrm{MW}$ (among them several at and/or slightly above $2 \mathrm{MW}$ ). It is therefore likely that the explosion of October 8 contributed to the reactivation of the fracture system associated with the hot fumaroles (Fig. 7, right images). This is also consistent with ground-based measurements.

\section{Conclusions}

Aso Volcano, also known as Nakadake, in north-central Kyushu has been characterized by a transition from phreatic-phreatomagmatic activity to Strombolian and vice versa. The summit of the volcano consists of a crater area with an active fumarole field and an acidic lake which is replaced by an inner pit crater during Strombolian phases, where the activity is concentrated. We have analyzed the thermal signature during unrest episodes by combining the MODIS-MIROVA data set (2000-2017) with high-resolution images (LANDSAT 8 OLI and Sentinel 2) together with ground-based thermal observations (2013-2017).

The typical cycle (e.g., Sudo 2001) normally starts with fumarolic activity, which then evolves to vapor and phreatic eruptions from the intra-crater Yudamari lake. During this stage, the volcanic radiative power (VRP) detected both by MODIS-MIROVA and ground-based FLIR T440 data was normally below 0.5 MW. With increasing activity, phreatic eruptions may be accompanied by the drying out of the water lake. This process is accompanied and/or followed by high fumarole activity (HFA, with measured apparent temperatures of $500-600{ }^{\circ} \mathrm{C}$ ) and normally preludes the onset of Strombolian activity which is characterized by the typically mild Strombolian eruptions, magma puffing from the inner summit vents, and occasionally by major Strombolian eruptions with the ejection of mafic pumiceous scorias (see Cigolini et al. 2008, 2015 for a summary of these eruptive styles at Stromboli). During this phase, the volcanic radiative power (VRP) detected by MODIS was well above the threshold of $2.8 \mathrm{MW}$, whereas groundbased heat fluxes fluctuated around $2 \mathrm{MW}$. This "apparent discrepancy" is due to the fact that satellite data record the combined effects of both the intra-crater thermal anomalies: the one of the Central Pit together with the one on the South Area.
However, prior, during and after the major Strombolian explosions (such as the one recorded on November 27, 2014) satellite VRP data are well above $10 \mathrm{MW}$, reaching peak values of $15.6 \mathrm{MW} 11$ days after the cited explosion. Following the ceasing of the Strombolian phase, the volcano has reentered the phreatic phase with the refilling of the water lake (that was replenished by early July 2016), locally accompanied by phreatomagmatic eruptions. During this phase, satellite data processed by MIROVA exhibit very few thermal alerts, whereas ground-based measurements initially were fluctuating around $1 \mathrm{MW}$, and then progressively decreased toward their minima. The most violent explosion occurred on October 8, 2016, and by the end of that month some of the detected heat fluxes (both by MODIS and FLIR) reached values above $2 \mathrm{MW}$. This is coeval with an increase in temperature of the fumarole field of the South Area, which reached values well above $300{ }^{\circ} \mathrm{C}$. It is therefore likely that the above explosion contributed to the resetting of the summit fracture network, enhancing fluid migration and moderately higher heat fluxes within the fumarole field.

In conclusion, we emphasize that thermal monitoring is a key parameter in volcano surveillance. We have hereby provided VRP threshold values that define the transition from phreatic-phreatomagmatic activity, through high fumarole activity (HFA), to a Strombolian phase at Nakadake. It is interesting to point out that, so far, similar VRP values have been recorded during the very early stages of unrest at Santa Ana volcano (from October 2004 to early January 2005, cf. Laiolo et al. 2017). The crosschecking between satellite data and ground-based measurements further proves that the firsts are sufficiently efficient in monitoring crater lake activity. These may be very useful during critical unrest episodes because they can minimize the exposure of researchers and technicians during field work. Moreover, their systematic collection and automated processing is an additional tool to investigate volcano dynamics and to mitigate volcanic risk at a larger scale.

\begin{abstract}
Authors' contributions
CC coordinated the cooperative project, integrated data analyses, and wrote the main part of the manuscript. DC performed satellite data collection and analysis by means of the MIROVA System; he also elaborated LANDSAT 8 OLI and Sentinel 2 images and reported their description. AY collected groundbased measurements and analyzed them, also providing specific images; he wrote a part of the manuscript dealing with this topic. ML performed satellite statistical data analysis and wrote this part of the manuscript. All authors read and approved the final manuscript.
\end{abstract}

\footnotetext{
Author details

${ }^{1}$ Dipartimento di Scienze della Terra, Università degli Studi di Torino, Via Valperga Caluso 35, Turin, Italy. ${ }^{2}$ Present Address: Aso Volcanological Laboratory, Institute for Geothermal Sciences, Graduate School of Science, Kyoto University, Noguchibaru 3088, Beppu, Oita 874-0903, Japan. ${ }^{3}$ Aso Volcanological Laboratory, Institute for Geothermal Sciences, Graduate School of Science, Kyoto University, 3028 Sakanashi, Aso, Kumamoto 869-2611, Japan. ${ }^{4}$ Dipartimento di Scienze della Terra, Università degli Studi di Firenze, Via G. La Pira 4, Florence, Italy.
} 


\section{Acknowledgements}

The first and third authors are indebted with T. Kagiyama and T. Ohkura for their encouragement in completing this work and providing valued advices during its advancement. Financial support from the Graduate School of Sciences of Kyoto University is gratefully acknowledged. Additional funds were provided by the University of Torino-Fondazione Compagnia di San Paolo to keep the MIROVA system efficiently operative. Special thanks to J. Fairley, D. Rouwet and an anonymous reviewer for their critical comments and suggestions.

\section{Competing interests}

The authors declare that they have no competing interests.

\section{Publisher's Note}

Springer Nature remains neutral with regard to jurisdictional claims in published maps and institutional affiliations.

Received: 9 November 2017 Accepted: 5 April 2018

Published online: 26 April 2018

\section{References}

Abe Y, Ohkura T, Shibutani T, Hirahara K, Kato M (2010) Crustal structure beneath Aso Caldera, Southwest Japan, as derived from receiver function analysis. J Volcanol Geotherm Res 195:1-12. https://doi.org/10.1016/j. jvolgeores.2010.05.011

Abe Y, Ohkura T, Shibutani T, Hirahara K, Yoshikawa S, Inoue H (2016) Lowvelocity zones in the crust beneath Aso caldera, Kyushu, Japan, derived from receiver function analyses. J Geophys Res 122:2013-2033. https:// doi.org/10.1002/2016JB013686

Bodruddoza Mia M, Nishijima J, Fujimitsu Y (2014) Exploration and monitoring geothermal activity using Landsat ETM + images - a case study at Aso volcanic area in Japan. J Volcanol Geotherm Res 275:14-21. https://doi. org/10.1016/j.jvolgeores.2014.02.008

Chiodini G, Vilardo G, Augusti V, Granieri D, Caliro S, Minopoli C, Terranova C (2007) Thermal monitoring of hydrothermal activity by permanent infrared automatic stations: results obtained at Solfatara di Pozzuoli, Campi Flegrei (Italy). J Geophys Res. https://doi.org/10.1029/2007JB005140

Christenson B, Németh K, Rouwet D, Tassi F, Vandemeulebrouck J, Varekamp JC (2015) Volcanic lakes. In: Rouwet D, Christenson B, Tassi F, Vandemeulebrouck J (eds) Volcanic lakes. IAVCEI advances in volcanology. pp 1-20. https://doi.org/10.1007/978-3-642-36833-2

Cigolini C, Laiolo M, Bertolino S (2008) Probing stromboli volcano from the mantle to paroxysmal eruptions. In: Zellmer G, Annen C (eds) Dynamics of crustal magma transfer, storage, and differentiation-integrating geochemical and geophysical constraints. Geological Society London Spec Pubbl vol 304, pp 33-70. https://doi.org/10.1144/sp304.3

Cigolini C, Laiolo M, Coppola D (2015) Revisiting the last major eruptions of Stromboli volcano: inferences on the role of volatiles during magma storage and decompression. In: Zellmer G (ed) The role of volaties in the genesis, evolution and eruption of arc magmas. Geological Society of London Spec Pubbl vol 410, pp 143-177. http://dx.doi.org/10.1144/ SP410.3

Committee for Catalog of Quaternary Volcanoes in Japan (1999) Catalog of quaternary volcanoes in Japan, Ver. 1.0. The Volcanol Soc of Japan Tokyo Japan: CD-ROM

Coppola D, Cigolini C (2013) Thermal regimes and effusive trends at Nyamuragira volcano (DRC) from MODIS infrared data. Bull Volcanol 75:1-15. https://doi.org/10.1007/s00445-013-0744-z

Coppola D, Laiolo M, Piscopo D, Cigolini C (2013) Rheological control on the radiant density of active lava flows and domes. J Volcanol Geotherm Res 249:39-48. https://doi.org/10.1016/j.jvolgeores.2011.12.001

Coppola D, Laiolo M, Delle Donne D, Ripepe M, Cigolini C (2014) Hot-spot detection and characterization of strombolian activity from MODIS infrared data. Int J Remote Sens 35(9):3403-3426. https://doi.org/10.1080 /01431161.2014.903354

Coppola D, Macedo O, Ramos D, Finizola A, Delle Donne D, del Carpio J, White McCausland W, Centeno R, Rivera M, Apaza F, Callata B, Chilo W, Cigolini
C, Laiolo M, Lazarte I, Machaca R, Masias P, Ortega M, Puma N, Taipe E (2015) Magma extrusion during the Ubinas 2013-2014 eruptive crisis based on satellite thermal imaging (MIROVA) and ground-based monitoring. J Volcanol Geotherm Res 302:199-210. https://doi.org/10.1016/j. jvolgeores.2015.07.005

Coppola D, Laiolo M, Cigolini C, Delle Donne D, Ripepe M (2016a) Enhanced volcanic hot-spot detection using MODIS IR data: results from the MIROVA system. In: Harris AJL, De Groeve T, Garel F, Carn SA (eds) Detecting, modelling and responding to effusive eruptions. Geol Soc Lond Spec Publ vol 426, pp 181-206. http://dx.doi.org/10.1144/SP426.5

Coppola D, Laiolo M, Lara LE, Cigolini C, Orozco G (2016b) The 2008 "silent" eruption of Nevados de Chillán (Chile) detected fromspace: effusive rates and trends from the MIROVA system. J Volcanol Geotherm Res 327:322-329. https://doi.org/10.1016/j.jvolgeores.2016.08.016

Coppola D, Campion R, Laiolo M, Cuoco E, Balagizi C, Ripepe M, Cigolini C, Tedesco D (2016c) Birth of a lava lake: nyamulagira volcano 2011-2015. Bull Volcanol 78(20):1-13. https://doi.org/10.1007/s00445-016-1014-7

Coppola D, Di Muro A, Peltier A, Villeneuve N, Ferrazzini V, Favalli M, Bachèlery P, Gurioli L, Harris AJL, Moune S, Vlastélic I, Galle B, Arellano S, Aiuppa A (2017a) Shallow system rejuvenation and magma discharge trends at Piton de la Fournaise volcano (La Réunion Island). Earth Planet Sci Lett 463:13-24. https://doi.org/10.1016/j.epsl.2017.01.024

Coppola D, Ripepe M, Laiolo M, Cigolini C (2017b) Modelling satellite-derived magma discharge to explain caldera collapse. Geology 45(6):523-526. https://doi.org/10.1130/G38866.1

Dean KG, Servilla M, Roach A, Foster B, Engle K (1998) Satellite monitoring of remote volcanoes improves study efforts in Alaska. EOS Trans Am Geophys Union 79:422-423

Dehn J, Dean KG, Engle K, Izbekov P (2002) Thermal precursors in satellite images of the 1999 eruption of Shishaldin Volcano. Bull Volcanol 64(8):525-534. https://doi.org/10.1007/s00445-002-0227-0

Fischer TP, Ramírez C, Mora-Amador RA, Hilton DR, Barnes JD, Sharp ZD, Le Brun M, de Moor JM, Barry PH, Füri E, Shaw AM (2015) Temporal variations in fumarole gas chemistry at Poás volcano, Costa Rica. J Volcanol Geotherm Res 294:56-70. https://doi.org/10.1016/j.jvolgeores.2015.02.002

Geographical Survey Institute (2004) Crustal deformations around Aso volcano. Report of Coordinating Committee for Prediction of Volcanic Eruptions vol 88, pp 106-110

Global Volcanism Program (2015) Report on Asosan (Japan). In: Wunderman $R$ (ed) Bulletin of the global volcanism network. Smithsonian Institution and US Geological Survey vol 40, p 2

Global Volcanism Program (2016) Report on Asosan (Japan). In: Sennert SK (ed) Weekly volcanic activity report. Smithsonian Institution and US Geological Survey: 20 April-26 April 2016

Global Volcanism Program (2017) Report on Asosan (Japan). In: Venzke E (ed) Bulletin of the global volcanism network smithsonian institution vol 42 p 5

Harris AJL (2013) Thermal remote sensing of active volcanoes. A user's Manual. Cambridge University Press, Cambridge, p 736

Harris AJL, Stevenson DS (1997) Thermal observations of degassing open conduits and fumaroles at Stromboli and Vulcano using remotely sensed data. JVolcanol Geotherm Res 76:175-198. https://doi.org/10.1016/ S0377-0273(96)00097-2

Harris AJL, Villeneuve N, Di Muro A, Ferrazzini V, Peltier A, Coppola D, Favalli M, Bachèlery P, Froger J-L, Gurioli L, Moune S, Vlastélic I, Galle B, Arellano S (2017) Effusive crises at Piton de la Fournaise 2014-2015: a review of a multi-national response model. J Appl Volcanol 6(1):11. https://doi. org/10.1186/s13617-017-0062-9

Hunter AG (1998) Intracrustal controls on the coexistence of tholeiitic and calc-alkaline magma series at Aso Volcano, SW Japan. J Petro 39(7):1255-1284

Hurst T, Hashimoto T, Terada A (2015) Crater lake energy and mass balance. In: Rouwet D, Christenson B, Tassi F, Vandemeulebrouck J (eds) Volcanic lakes. IAVCEI Advances in Volcanology, pp 307-321. https://doi. org/10.1007/978-3-642-36833-2_13

Ikebe S, Watanabe I, Miyabuchi Y (2008) The sequence and style of the 1988 1995 eruptions of Nakadake Aso Volcano, Kyushu, Japan. Bull Volcanol Soc Japan 53:15-33 (in Japanese with English abstract)

Japan Meteorological Agency (2013) National catalogue of the active volcanoes in Japan, 4th edn. http://www.data.jma.go.jp/svd/vois/data/tokyo/ STOCK/souran_eng/volcanoes/084_asosan.pdf 
Kagiyama T (1981) Evaluation methods of heat discharge and their applications to the major active volcanoes in Japan. J Volcanol Geotherm Res 9:87-97

Kamata H, Kodama K (1994) Tectonics of an arc-arc junction: an example from Kyushu Island at the junction of the Southwest Japan Arc and the Ryukyu Arc. Tectonophysics 233:69-81

Kaneko K, Koyaguchi T, Takahashi T (2008) Crustal processes of magmas in large-scale silicic volcanism - a review and new insights on Aso volcano. Chikyu Mon Gogai 60:187-197

Koike K, Yoshinaga T, Asaue H (2014) Characterizing long-term radon concentration changes in a geothermal area for correlation with volcanic earthquakes and reservoir temperatures: a case study from Mt. Aso, southwestern Japan. J Volcanol Geotherm Res 275:85-102. https://doi. org/10.1016/j.jvolgeores.2014.02.007

Laiolo M, Coppola D, Barahona F, Benítez JE, Cigolini C, Escobar D, Funes R, Gutierrez E, Henriquez B, Hernandez A, Montalvoe F, Olmos R, Ripepe M, Finizola A (2017) Evidences of volcanic unrest on high-temperature fumaroles by satellite thermal monitoring: the case of Santa Ana volcano, El Salvador. J Volcanol Geotherm Res 340:170-179. https://doi. org/10.1016/j.jvolgeores.2017.04.013

Matsumoto A, Uto K, Ono K, Watanabe K (1991) K-Ar age determinations for Aso volcanic rocks-concordance with volcanostratigraphy and application to pyroclastic flows. Programme Abstr Volcanol Soc Jpn 2:73

Matsushima N, Kazahaya K, Saito G, Shinohara H (2003) Mass and heat flux of volcanic gas discharging from the summit crater of Iwodake volcano, Satsuma-Iwojima, Japan, during 1996-1999. J Volcanol Geotherm Res 126:285-301

McKee K, Fee D, Yokoo A, Matoza RS, Kim K (2017) Analysis of gas jetting and fumarole acoustics at Aso Volcano, Japan. J Volcanol Geotherm Res 340:16-29. https://doi.org/10.1016/j.jvolgeores.2017.03.029

Miyabuchi Y, Sugiyama S (2011) 90,000-year phytolith record from tephra section at the northeastern rim of Aso caldera, Japan. Quat Int 246(1):239-246

Miyabuchi Y, Watanabe K, Egawa Y (2006) Bomb-rich basaltic pyroclastic flow deposit from Nakadake, Aso Volcano, southwestern Japan. J Volcanol Geotherm Res 155:90-103

Miyabuchi Y, Ikebe S, Watanabe K (2008) Geological constraints on the 20032005 ash emissions from the Nakadake crater lake, Aso volcano Japan. J Volcanol Geotherm Res 178(2):169-183. https://doi.org/10.1016/j. jvolgeores.2008.06.025

Miyoshi M, Shinmura T, Sumino H, Sano T, Miyabuchi Y, Mori Y, Inakura H, Furukawa K, Uno K, Hasenaka T, Nagao K, Arakawa Y, Yamamoto Y (2013) Lateral magma intrusion from a caldera-forming magma chamber: constraints from geochronology and geochemistry of volcanic products from lateral cones around the Aso caldera, SW Japan. Chem Geol 352:2002-2210

Murphy SW, de Souza Filho CR, Wright R, Sabatino G, Pabon RC (2017) HOTMAP: global hot target detection at moderate spatial resolution. Remote Sens Environ 177:78-88

Murphy S, Wright R, Rouwet D (2018) Color and temperature of the crater lakes at Kelimutu volcano through time. Bull Volcanol 80(1):2. https://doi. org/10.1007/s00445-017-1172-2

Németh K, Cronin SJ, Charley D, Harrison M, Garae E (2006) Exploding lakes in Vanuatu "Surtseyan-style" eruptions witnessed on Ambae Island. Episodes 29(2):87-92

Nobile A, Acocella V, Ruch J, Aoki Y, Borgstrom S, Siniscalchi V, Geshi N (2017) Steady subsidence of a repeatedly erupting caldera through InSAR observations: Aso, Japan. Bull Volcanol 79:32. https://doi.org/10.1007/ s00445-017-1112-1

Ohkura T, Oikawa J (2012) GPS observation of crustal deformation at Aso volcano. Chikyu Mon Gogay 34(12):706-711

Ohsawa S, Saito T, Yoshikawa S, Mawatari H, Yamada M, Amita K, Takamatsu N, Sudo Y, Kagiyama T (2010) Color change of lake water at the active crater lake of Aso volcano, Yudamari, Japan: Is it in response to change in water quality induced by volcanic activity? Limnology 11:207-215. https://doi. org/10.1007/s10201-009-0304-6

Onda Y, Ohsawa S, Takamatsu N (2003) A colorimetric and geochemical study of the coloration factor of hyper-acid active crater lakes (in Japanese). Jpn $J$ Limnol 64:1-10 (in Japanese with Abstract in English)

Ono K, Watanabe K (1985) Geological map of Aso volcano. Geol Surv, Japan
Ono K, Watanabe K, Hoshizumi H, Ikebe S (1996) Ash eruption of the Nakadake crater, Aso volcano, southwestern Japan. Bull Volcanol 66:137-148

Oppenheimer C (1993) Infrared surveillance of crater lakes using satellite data. J Volcanol Geotherm Res 55(1-2):117-128. https://doi. org/10.1016/0377-0273(93)90093-7

Oppenheimer C (1996) Crater lake heat losses estimated by remote sensing. Geophys Res Lett 23(14):1793-1796. https://doi.org/10.1029/96GL01591

Oppenheimer C (1997) Remote sensing of the color and temperatures of volcanic lakes. Int J Rem Sens 18(1):5-37. https://doi. org/10.1080/014311697219259

Patrick MR, Smellie JL, Harris AJL, Wright R, Dean K, Izbekov P, Garbeil H, Pilger E (2005) First recorded eruption of Belinda volcano (Montagu Island), South Sandwich Islands. Bull Volcanol 67:415-422. https://doi.org/10.1007/ s00445-004-0382-6

Ramsey MS, Harris AJL (2012) Volcanology 2020: how will thermal remote sensing of volcanic surface activity evolve over the next decade? J Volcanol Geotherm Res 249:217-233. https://doi.org/10.1016/j. jvolgeores.2012.05.011

Research group for active faults of Japan (1991) Active faults in Japan. Sheet maps and inventories, revised edn. University of Tokyo Press, Tokyo

Rothery DA, Coppola D, Saunders C (2005) Analysis of volcanic activity patterns using MODIS thermal alerts. Bull Volcanol 67(6):539-556. https://doi. org/10.1007/s00445-004-0393-3

Rouwet D, Tassi F (2011) Geochemical monitoring of volcanic lakes. A generalized box model for active crater lakes. Ann Geophys 54(2):161-173. https://doi.org/10.4401/ag-5035

Sekioka M (1983) Proposal of a convenient version of the heat balance technique estimating heat flux on geothermal and volcanic fields by means of infrared remote sensing. Mem Natl Def Acad Jpn 23(2):95-103

Sekioka M, Yuhara K (1974) Heat flux estimation in geothermal areas based on the heat balance of the ground surface. J Geophys Res 79:2053-2058

Shinohara H, Yoshikawa S, Miyabuchi Y (2015) Degassing activity of a volcanic crater lake: Volcanic plume measurements at the Yudamari crater lake: Aso volcano, Japan. In: Rouwet D, Christenson B, Tassi F, Vandemeulebrouck J (eds) Volcanic Lakes. Springer, Heidelberg, p 201. https://doi. org/10.1007/978-3-642-36833-2_8

Sudo Y (2001) The character of volcanic activity at Aso volcano: an open system volcano. Chikyu Mon 23:545-550 (in Japanese)

Sudo Y, Kong L (2001) Three-dimensional seismic velocity structure beneath Aso volcano Kyushu, Japan. Bull Volcanol 63:326-344

Sudo Y, Tsutsui T, Nakaboh M, Yoshikawa M, Yoshikawa S, Inoue H (2006) Ground deformation and magma reservoir at Aso volcano: location of deflation source derived from long-term geodetic surveys. Kazan 51(5):291-309 (in Japanese)

Takayama H, Yoshida A (2007) Crustal deformation in Kyushu derived from GEONET data. J Geophys Res 112(B6):B06413

Terada A, Hashimoto T (2017) Variety and sustainability of volcanic lakes: Response to subaqueous thermal activity predicted by a numerical model. J Geophys Res Solid Earth 122:6108-6130. https://doi. org/10.1002/2017jb014387

Trunk L, Bernard A (2008) Investigating crater lake warming using ASTER thermal imagery: case studies at Ruapehu, Poa's, Kawahljen, and Copahue' Volcanoes. J Volcanol Geotherm Res 178:259-270

Tsutsui T, Sudo Y (2004) Seismic reflectors beneath the central cones of Aso Volcano, Kyushu, Japan. J Volcanol Geotherm Res 131:33-58

Unglert K, SavageMK Fournier N, Ohkura T, Abe Y (2011) Shear wave splitting, VP/VS, and GPS during a time of enhanced activity at Aso caldera, Kyushu. J Geophys Res 116:B11203. https://doi.org/10.1029/2011JB008520

Valade S, Lacanna G, Coppola D, Laiolo M, Pistolesi M, Delle Donne D, Genco R, Marchetti E, Ulivieri G, Allocca C, Cigolini C, Nishimura T, Poggi P, Ripepe M (2016) Tracking dynamics of magma migration in openconduit systems. Bull Volcanol 78(11):78-90. https://doi.org/10.1007/ s00445-016-1072-X

Wooster MJ, Zhukov B, Oertel D (2003) Fire radiative energy for quantitative study of biomass burning: derivation from the BIRD experimental satellite and comparison to MODIS fire products. Remote Sens Environ 86:83-107

Wright R, Flynn L, Garbeil H, Harris A, Pilger E (2002) Automated volcanic eruption detection using MODIS. Remote Sens Environ 82(1):135-155

Yagi Y, Okuwaki R, Enescu B, Kasahara A, Miyakawa A, Otsubo M (2016) Rupture process of the 2016 Kumamoto earthquake in relation with the thermal 
structure around Aso volcano. Earth Planets Space 68(1):1-6. https://doi. org/10.1186/s40623-016-0492-3

Yamamoto M, Kawakatsu H, Kaneshima S, Mori T, Tsutsui T, Sudo Y, Morita Y (1999) Detection of a crack-like conduit beneath the active craterat Aso volcano, Japan. Geophys Res Lett 26:3677-3680. https://doi. org/10.1029/1999GL005395
Yokoo A, Taniguchi H (2004) Application of video image processing to detect volcanic pressure waves: a case study on archived images of Aso Volcano, Japan. Geophys Res Lett 31:L23604. https://doi.org/10.1029/20 04GL021183
Submit your manuscript to a SpringerOpen ${ }^{\odot}$ journal and benefit from:

- Convenient online submission

- Rigorous peer review

- Open access: articles freely available online

- High visibility within the field

- Retaining the copyright to your article

Submit your next manuscript at $\boldsymbol{\nabla}$ springeropen.com 